\title{
Assessing The Appearance Of Auditor Independence Using Behavioral Research Methodology
}

Gary Colbert, University of Colorado at Denver, USA

Dennis Murray, University of Colorado at Denver, USA

Robert Nieschwietz, University of Colorado at Denver, USA

\begin{abstract}
Recent archival studies have examined the association between auditor independence and nonaudit services. The results of these studies suggest that fees for non-audit services are not associated with indicators of auditor independence in fact whereas these fees are associated with financial statement users' perceptions of auditor independence (i.e., independence in appearance). The present study attempts to reconcile these conflicting findings by using a behavioral research methodology that provides greater control over the independent variables and measures more directly financial statement users' perceptions. Our results indicate that fees for financial information systems development services do not affect perceptions of auditor independence, whereas, fees for tax services adversely affect perceptions of independence. Overall, the results provide mixed support for the recent Securities and Exchange Commission policy changes on auditor independence.
\end{abstract}

Keywords: auditor independence, independence, behavioral research

\section{INTRODUCTION}

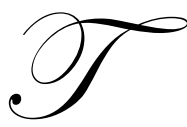

he Sarbanes-Oxley Act of 2002 (SOX) took a number of steps to prevent corporate failures and accounting scandals, and to restore the faith of investors in the credibility of financial statements. Title II of SOX includes several provisions that are designed to enhance auditor independence. These provisions proscribe auditors of publicly held corporations from providing certain non-audit services (NAS) to audit clients, require that both audit services and NAS be pre-approved by audit committees, and require corporations to disclose the NAS provided by their auditors. Prior to the passage of SOX, the SEC required corporations to disclose fees paid to their auditors for audits and NAS (SEC 2000). Subsequent to SOX, the SEC retained, but modified, these disclosure rules (SEC 2003).

Several recent archival studies (Ashbaugh et al. 2003, Chung and Kallapur 2003, Frankel et al. 2002, Kinney et al. 2004, and Reynolds et al. 2004) have examined the association between fees (audit and non-audit) paid to an auditor and various measures of earnings quality. This relationship is of importance because a negative association between fees and earnings quality would suggest that an auditor's independence had been compromised due to high fees. To date, the bulk of the evidence from these studies indicates that no association exists between fees and earnings quality (DeFond and Francis 2005). Interestingly, Kinney et al. (2004) report that tax fees are negatively associated with financial statement restatements, suggesting that tax services have a desirable effect on earnings quality.

The archival studies cited above deal with the concept of auditor independence in fact. The earnings quality and audit quality measures (e.g., discretionary accruals and the frequency of clean audit opinions) used in those studies are designed to capture an auditor's acquiescence with a client's questionable accounting policy preference. 
That is, the earnings quality and audit quality measures reflect whether the auditor's independence was, in fact, compromised. The SEC, among others, has emphasized the importance of both independence in fact and independence in appearance. Independence in appearance refers to financial statement users' perceptions of auditor independence. The SEC has taken the position that an auditor would not be considered to be independent if "a reasonable investor, with knowledge of all relevant facts and circumstances, would conclude that the auditor is not capable of exercising objective and impartial judgment" (SEC 2000). Thus, the SEC views the appearance of independence as a necessary element of auditor independence.

Several additional archival studies have examined the association between non-audit fees and indicators of investors' perceptions of auditor independence. For example, Mishra et al. (2005) found a positive association between fees for NAS (including tax services) and the proportion of shareholder votes against shareholder ratification. This result suggests that shareholders are troubled by the NAS provided by their auditor, presumably because the fee for these services compromises the auditor's independence. Moreover, the result for tax services contrasts with the findings of Kinney et al. 2004. Additionally, Krishnan et al. (2005) found a negative association between NAS fees and earnings response coefficients. This result indicates that capital market participants find earnings to be less useful when the auditor receives a higher fee for NAS. The reduced usefulness of earnings is again presumably due to impaired auditor independence and diminished financial statement reliability.

The results of the archival studies addressing auditor independence in fact differ markedly from the results of the archival studies addressing auditor independence in appearance. The former studies generally find no association between fees for NAS and earning quality. The latter studies generally find a negative association between fees for NAS and perceptions of auditor independence. What might account for the conflicting results? One explanation is that both sets of results are valid. The case may be that fees for NAS do not affect independence in fact but do affect perceptions of independence. Another possibility relates to methodological issues. Although archival studies have the advantage of using real world data, the causal connection between the independent and dependent variable is not directly examined because the researcher does not control administration of the treatments. Moreover, the possible presence of uncontrolled variables and measurement issues (e.g., is the earnings response coefficient a valid indicator of perceptions of auditor independence) may confound the results of the archival studies.

Our study complements the recent archival studies by examining the appearance of auditor independence using a behavioral research methodology. The study tests, in a controlled environment, if the provision of NAS to audit clients affects financial statement users' perceptions of auditor independence. Our study examines the reactions of lending officers to the disclosure of fees for two types of NAS: financial information system design and implementation services (FISDIS) and tax services. The disclosures are patterned after those required by the SEC. Our results show that the provision of tax services, but not FISDIS services, is associated with lender's perceptions and their loan decisions.

The remainder of the paper is organized as follows. The second section presents the motivation and research questions, the third section describes our results and the final section offers a summary and conclusions.

\section{MOTIVATION AND HYPOTHESES}

Simunic (1984) and Beck et al. (1988a) have modeled the relationship between auditor independence and NAS provided by an auditor to an audit client. They demonstrate that the auditor-client economic bond can be strengthened if the auditor provides NAS to the client. This economic bond provides the auditor with greater financial incentives to accede to the client's preferences regarding accounting policy choices, thus potentially compromising the auditor's independence. However, countervailing forces such as codes of ethics, personal integrity, accounting firm policies, and the desire to maintain reputational capital could prevent the financial incentives from affecting an auditor's independence. Beck et al. (1988a, p. 50) state that while the "incentives do not necessarily create an independence problem in fact, the appearance of auditor independence may be diminished." That is, a financial statement user's perception of auditor independence could be affected by knowledge about the contractual agreement between the auditor and its client, even if the auditor's actual independence is unaffected. 
Numerous behavioral studies have examined whether financial statement users' perceptions of auditor independence are affected by the auditor providing NAS to audit clients. Some early studies (e.g., Shockley 1981), using a within-subjects design, found an effect of providing NAS. Later studies (e.g., McKinley et al. 1985, Pany and Reckers 1987, 1988), using between-subjects designs, found that perceptions of auditor independence were unaffected by the auditor providing NAS to audit clients. The significant findings of the within-subjects studies are likely due to demand effects. On balance, these studies indicate that financial statement users do not believe that an auditor's independence is compromised by providing NAS to audit clients.

All of the above studies dealing with perceptions of auditor independence were conducted prior to the spate of accounting scandals that were revealed at the beginning of the current millennium. Dopuch et al. (2003) document over 1,100 articles on auditor independence in the popular press during 2000 and 2001. On average, during the preceding 10 years, nine articles per year mentioning auditor independence appeared. The dramatic increase in media attention to auditor independence may have increased financial statement users' sensitivity to the issue. This suggests that the results of prior studies assessing perceptions of auditor independence may not generalize to the current environment. ${ }^{1}$

In our study, we examine how loan officers react to auditors providing 1) FISDIS and 2) tax services to audit clients. Given that SOX precludes auditors from providing FISDIS to audit clients, assessing how financial statement users react to disclosures about an auditor providing these services might seem questionable. However, we believe that our results will prove useful to both the SEC and state regulators. Most of the archival studies previously cited find no relationship between fees for NAS and independence in fact. One of those studies (Kinney et al. 2004) specifically finds no association with respect to FISDIS. If these results are valid, the advisability of the SEC's proscriptions is brought into question. However, the SEC is also vitally interested in the effect that providing NAS has on the appearance of auditor independence. Even if auditors maintain their independence in fact when providing NAS to audit clients, financial statement users' perceptions of independence could be affected, thus compromising the credibility of financial statements.

State regulators can also benefit from the results of this study. Section 209 of SOX directs them to evaluate which, if any, provisions of SOX should be implemented at the state level. State regulators have the options of banning auditors from providing certain NAS, of requiring fee disclosures, or of maintaining the status quo. Knowledge about users' perceptions of auditor independence should be of help to them in making this choice.

We chose to study lenders' reactions to auditors providing tax services to audit clients for several reasons. First, the economic bond between an auditor and its client can be strengthened not only by the auditor providing management consulting services, but also by tax services. Moreover, the provision of tax services can be an enduring relationship. Second, the SEC's new fee disclosure requirements (SEC 2003) now require corporations to disclose fees paid to auditors for tax services. Third, fees paid for tax services are very significant in relation to audit fees (Kinney et al. 2004). Fourth, the Public Company Accounting Oversight Board (PCAOB) has recently begun to evaluate the possible implications that providing tax services to audit clients might have on an auditor's independence (PCAOB 2004). Finally, there have been very few published behavioral studies that have examined the impact of tax services on perceptions of auditor independence. ${ }^{2}$

Our first two hypotheses in alternative form are:

H1: Lenders' perceptions and loan decisions are negatively affected when an auditor provides FISDIS to an audit client.

H2: Lenders' perceptions and loan decisions are negatively affected when an auditor provides tax services to an audit client.

We also examine if the joint presence of both FISDIS and tax services interact in their effect on users. If just one service is provided by an auditing firm, presumably at least one audit partner and one NAS partner (the ultimate decision makers in a firm) would have a financial interest in pleasing the client. If both FISDIS and tax 
services are provided, at least one additional partner would have a similar interest. In such a situation, the pervasive involvement of high level auditing firm personnel with the client might suggest to users that a line has been crossed from limited involvement with the client to extensive involvement, thus compromising the auditing firm's independence. The third hypothesis is:

H3: The provision of FISDIS and tax services together negatively interact in their effects on lenders' perceptions and loan decisions.

\section{RESEARCH METHOD}

We requested loan officers to react to a hypothetical case involving a new loan applicant. Each subject received identical case materials except for the manipulated experimental treatment of NAS fee level. The participants were asked to indicate their views of the auditor's independence, the credibility of the financial statements and to indicate if they would grant a loan to the hypothetical applicant. A between-subjects design was used to avoid the demand effects mentioned previously.

\section{Participants}

Loan officers were used as subjects in this study for several reasons. First, creditors are a major user of the financial statements of publicly held corporations. Therefore, the reactions of lenders should be of interest to federal regulators, such as the SEC and PCAOB. Lenders are also a major user of private companies' financial statements and private companies elect to be audited to reduce lending costs (Blackwell et al. 1998). Thus, lenders' reactions should also be of interest to state regulators who might be considering the adoption of SOX-like provisions. Finally, loan officers have been used in numerous prior studies (e.g., McKinley et al. 1985). Using subjects similar to those employed in previous studies will help assess if financial statement users' views have changed in a post-Enron environment.

Fifteen hundred loan officers were randomly selected from a commercially available nation-wide database. Each participant was sent a packet of materials and asked to participate in the study. One hundred thirty-one responses were received. ${ }^{3}$

Non-response bias was examined by comparing the replies of early and late responders. No significant differences were noted on the demographic and dependent variables.

\section{Materials}

Participants were provided with a packet containing a cover letter, the experimental instrument and a return envelope. The cover letter explained the general purpose of the research and requested the participant to respond within a timely period. The instrument contained a general description of the hypothetical loan applicant (including brief biographies of the president, vice-president for marketing, and vice-president of finance and controller (one position)), the purpose of the requested loan, summary financial statement information ${ }^{4}$ and calculated ratios for two years, information about fees paid to the auditor, and a questionnaire. The materials were patterned after similar prior studies of perceptions of auditor independence (e.g., Lowe and Pany 1995).

\section{Independent Variables}

The information about fees paid to the auditor was patterned after SEC disclosure requirements. Two years of both financial statement information and fee data were supplied. The audit fee for the second year was set slightly higher than the first year, but audit fees were held constant in all treatments. The fee for each type of NAS (FISDIS and tax services) was set at one of two levels: either zero or $30 \%$ of the audit fee in each year. ${ }^{5}$ Our goal was to set the non-zero fee level high enough to be substantially different from zero, yet not unrealistically high. 
Although the two-year format provided us the opportunity to manipulate fee level across years, we kept the NAS fee level the same each year (in relation to the audit fee) for two reasons. First, maintaining the same fee level should strengthen the effect of the experimental treatments. Second, Beck et al. (1988b) provide limited evidence that both FISDIS and tax services are relatively recurring. Therefore, maintaining the same fee level should improve the study's external validity.

\section{Experimental Design}

Table 1 summarizes the experimental design used in the study. To assess the effect of NAS fee level (Hypotheses 1 and 2) and whether NAS type (FISDIS and tax) interact (Hypothesis 3), the two levels of FISDIS fees were crossed with the two levels of tax fees.

Table 1

Experimental Design

\begin{tabular}{|c|c|c|}
\hline \multicolumn{3}{|c|}{ Tax Services x FISDIS } \\
\hline & & \\
\hline & $0 \%$ & $30 \%$ \\
\hline \multicolumn{3}{|l|}{ Tax Services Fee } \\
\hline $0 \%$ & $\begin{array}{c}\text { Group 1 } \\
n=29\end{array}$ & $\begin{array}{c}\text { Group 3 } \\
n=27\end{array}$ \\
\hline $30 \%$ & $\begin{array}{c}\text { Group } 2 \\
n=30\end{array}$ & $\begin{array}{c}\text { Group 4 } \\
\mathrm{N}=27\end{array}$ \\
\hline
\end{tabular}

\section{Dependent Variables}

The questionnaire asked participants how confident they were in the auditor's independence. An 11-point scale anchored on 0 (Low Confidence) and 10 (High Confidence) was used. Participants were also asked to rate the reliability of the financial statements. Again, an 11-point scale was used. The anchors were 0 (Not Very Reliable) and 10 (Very Reliable). These questions directly address the effect of the independent variables on the appearance of auditor independence and on perceived financial statement reliability. Participants were also asked to indicate if they would approve the loan. ${ }^{6}$

Examination of the correlation among the dependent variables shows that respondents treated these questions in a consistent manner. The three variables were all positively correlated (at p-values less than .05).

\section{Manipulation Checks}

Manipulation checks were used to assess if the participants attended to the independent variables. Subjects were asked to recall, without looking back at the case, if the loan applicant paid its auditor any fees in addition to the audit service fee and whether an officer of the loan applicant was previously employed by the applicant's CPA firm. Respondents were also asked if they had previous experience with a loan of this size. Eighteen respondents failed the check or indicated they had not handled loans of this size and were eliminated from the statistical analysis. ${ }^{7}$

\section{Respondents' Demographics}

Table 2 summarizes the respondents' demographic characteristics. Of particular note, the respondents have considerable loan experience. Respondents reported having an average of more than 20 years of loan experience. ${ }^{8}$ They also report a good understanding of accounting. The demographics appear comparable to those reported in other recent studies that use loan officers as subjects (e.g., Lowe et al. 1999 and Lowe and Pany 1995). 
Table 2

Loan Officer Demographics

\begin{tabular}{|c|c|c|c|c|c|}
\hline & Group 1 & Group 2 & Group 3 & Group 4 & Total \\
\hline Sample size & 29 & 30 & 27 & 27 & 113 \\
\hline \multicolumn{6}{|l|}{ Age } \\
\hline Average & 46.93 & 46.47 & 50.41 & 47.11 & 47.68 \\
\hline Standard Deviation & 8.37 & 9.46 & 9.32 & 9.25 & \\
\hline \multicolumn{6}{|l|}{ Loan Experience } \\
\hline Average & 21.14 & 18.13 & 23.33 & 21.73 & 21.00 \\
\hline Standard Deviation & 7.79 & 9.15 & 8.74 & 8.41 & \\
\hline \multicolumn{6}{|c|}{ Understanding of Accounting } \\
\hline Average & 7.89 & 7.61 & 7.59 & 7.63 & 7.68 \\
\hline Standard Deviation & 1.55 & 1.23 & 1.37 & 1.45 & \\
\hline \multicolumn{6}{|l|}{ Title } \\
\hline President & 4 & 3 & 3 & 5 & 15 \\
\hline Vice-President & 21 & 21 & 20 & 19 & 81 \\
\hline Loan Officer & 1 & 4 & 3 & 0 & 8 \\
\hline Other & 3 & 2 & 1 & 3 & 9 \\
\hline \multicolumn{6}{|l|}{ Type of Institution } \\
\hline Bank & 28 & 25 & 27 & 23 & 103 \\
\hline Savings \& Loan & 0 & 3 & 0 & 0 & 3 \\
\hline Thrift & 0 & 1 & 0 & 3 & 4 \\
\hline Credit Union & 0 & 1 & 0 & 0 & 1 \\
\hline Other & 1 & 0 & 0 & 1 & 2 \\
\hline
\end{tabular}

\section{RESULTS}

To test our hypotheses we use ANOVA models for two of the dependent variables: confidence in the auditor's independence and reliability of the financial statements. ${ }^{9}$ Because the loan decision dependent variable is binary in nature we use a logistic regression model which is deemed more appropriate (Neter et al. 1985) in such cases.

Tables 3 and 4 report group statistics and ANOVA results for the dependent variables confidence in the auditor's independence and reliability of the financial statements, respectively. Table 5 reports group statistics and the logistic regression results for the loan decision dependent variable. The first hypothesis is that lenders' perceptions and loan decisions are negatively affected if an auditor provides FISDIS to an audit client. The ANOVA and logistic regression results show FISDIS has no statistically significant effect across the three dependent variables. The results are consistent with the provision of FISDIS services by auditors not affecting lenders' perceptions and loan decisions.

The second hypothesis is that lenders' perceptions and loan decisions are negatively affected if an auditor provides tax services to an audit client. The ANOVA results in Table 3 and Table 4 and the logistic regression results in Table 5 show that providing tax services is marginally significant statistically. The p-values are .08, .11, and .09, for perceptions of confidence in the auditor's independence, perceptions of financial statement reliability, and the loan decision, respectively. ${ }^{10}$ Inspection of the cell means in Table 3, Table 4, and Table 5 show that when tax services are provided, the lenders were less confident that the auditor was independent, view the financial statements as being less reliable, and are less likely to approve the loan. Overall the results are consistent with the provision of tax services by auditors affecting lenders' perceptions and loan decisions.

The third hypothesis is that the provision of FISDIS and tax services together increase the negative effect on lenders' perceptions and loan decisions. The ANOVA and logistic regression results show no statistically significant interactions for any of the three dependent variables. 
Table 3

Dependent Variable: Confidence in the Auditor's Independence

\section{Panel A:}

\section{Cell Means (Std Dev)}

\begin{tabular}{c|ccc} 
& 0\% FISDIS & 30\% FISDIS & Total \\
\hline 0\% Tax & $7.45(2.16)$ & $6.93(1.88)$ & $7.20(2.03)$ \\
30\% Tax & $6.37(2.04)$ & $6.56(2.56)$ & $6.46(2.28)$ \\
Total & $6.90(2.16)$ & $6.74(2.23)$ & $6.82(2.18)$
\end{tabular}

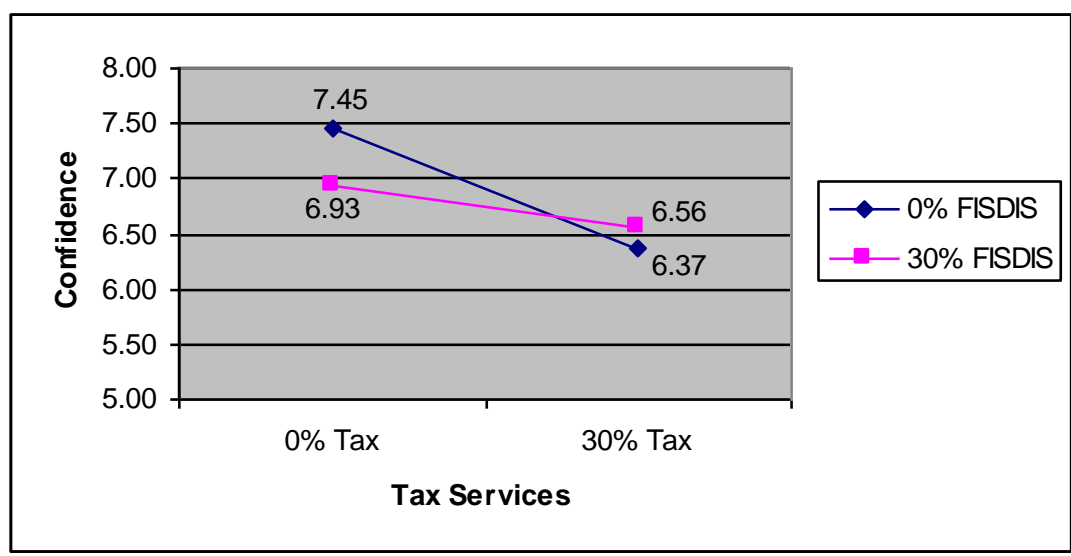

Panel B:

ANOVA Analysis

\begin{tabular}{|l|c|c|}
\hline \multicolumn{1}{|c|}{ Variable } & F-Value & Pr>F \\
\hline FISDIS & 0.17 & 0.69 \\
\hline Tax & 3.15 & 0.08 \\
\hline FISDIS X Tax & 0.76 & 0.39 \\
\hline
\end{tabular}


Table 4

Dependent Variable: Reliability of the Financial Statements

\section{Panel A:}

\section{Cell Means (Std Dev)}

\begin{tabular}{c|ccc} 
& 0\% FISDIS & 30\% FISDIS & Total \\
\hline 0\% Tax & $7.21(2.14)$ & $7.04(1.85)$ & $7.13(1.99)$ \\
30\% Tax & $6.20(2.19)$ & $6.74(2.28)$ & $6.46(2.23)$ \\
Total & $6.69(2.21)$ & $6.89(2.06)$ & $6.79(2.13)$
\end{tabular}

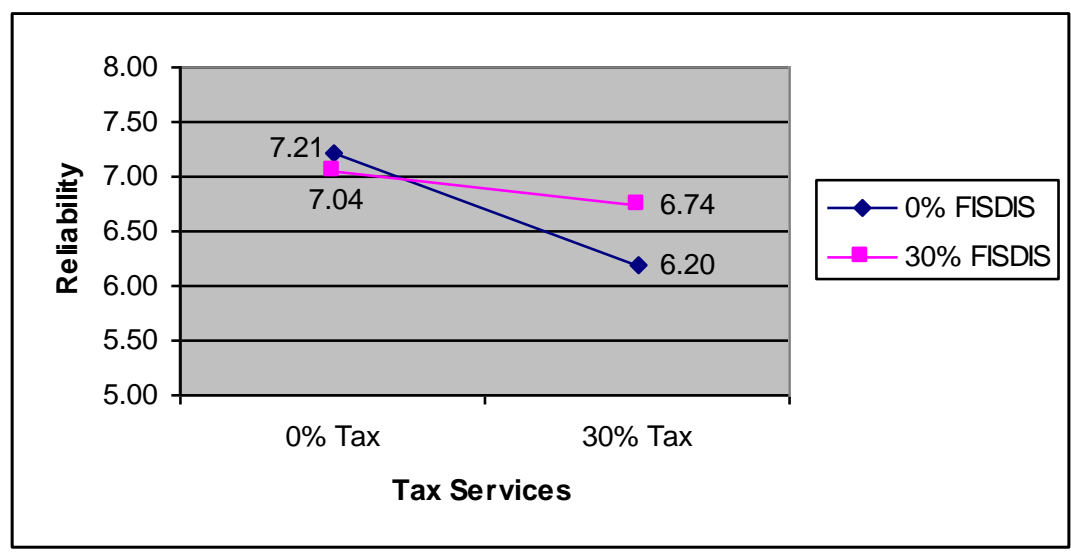

Panel B:

ANOVA Analysis

\begin{tabular}{|l|c|c|}
\hline \multicolumn{1}{|c|}{ Variable } & F-Value & \multicolumn{2}{c|}{ Pr>F } \\
\hline FISDIS & 0.21 & 0.64 \\
\hline Tax & 2.65 & 0.11 \\
\hline FISDIS X Tax & 0.79 & 0.38 \\
\hline
\end{tabular}


Table 5

Dependent Variable: Loan Decision

\section{Panel A:}

\section{Cells Means (Std Dev)}

\begin{tabular}{c|ccc} 
& 0\% FISDIS & 30\% FISDIS & Total \\
\hline 0\% Tax & $.62(.49)$ & $.63(.49)$ & $.63(.49)$ \\
30\% Tax & $.43(.50)$ & $.50(.51)$ & $.46(.50)$ \\
Total & $.53(.50)$ & $.57(.50)$ & $.54(.50)$
\end{tabular}

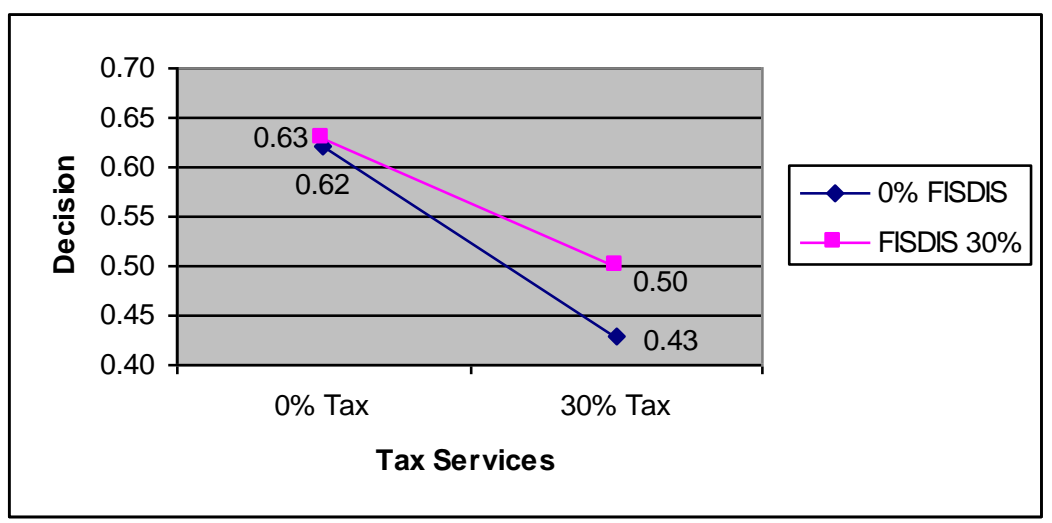

\section{Panel B:}

\section{Logistic Regression Analysis}

\begin{tabular}{|l|c|c|}
\hline \multicolumn{1}{|c|}{ Variable } & Chi-Squrare & \multicolumn{2}{c|}{ Pr>ChiSq } \\
\hline FISDIS & 0.16 & 0.69 \\
\hline Tax & 2.80 & 0.09 \\
\hline FISDIS X Tax & 0.09 & 0.77 \\
\hline
\end{tabular}

Overall, the results on the three hypotheses are mixed. Consistent with studies conducted prior to the accounting scandals at the beginning of the current millennium, we find that providing FISDIS services does not affect lenders' perceptions and loan decisions. In contrast, we find that providing tax services negatively affects perceptions of auditor independence, reliability of financial statements, and reduces the likelihood that lenders will approve the loan. Perhaps lenders perceive that tax services are more enduring and create a stronger economic bond between the auditor and its client.

\section{SUMMARY AND CONCLUSIONS}

This paper provides updated evidence on the appearance of auditor independence in the new millennium using a behavioral methodology. Recent archival studies have examined the association between proxies for auditor independence and auditor fees, including NAS fees. However, we are not aware of any behavioral studies that have examined the effect of NAS on the appearance of auditor independence subsequent to the recent wave of accounting scandals and the related media coverage. We have two principle findings.

First, we find no association between the provision of FISDIS by auditors and lender's perceptions and loan decisions. This result is consistent with the recent archival studies that examined independence in fact, but conflicts 
with the archival studies that addressed independence in appearance. Although additional research is needed to resolve these differing findings, the archival and behavioral results, taken together, call into question the SEC proscription of FISDIS by auditors and suggest that state regulators should proceed cautiously with their deliberations regarding the adoption of such a proscription.

Second, in contrast to our results regarding FISDIS, we find evidence that tax services provided by auditors negatively affects lender's perceptions and loan decisions. This result is consistent with the archival research on independence in appearance but inconsistent with the archival research on independence in fact. Kinney et al. (2004) document a negative association between tax services and restatements (a proxy for lower audit quality and impairment of independence in fact), suggesting that increased tax services by auditors are associated with improved financial reporting quality. If confirmed by future research, these findings indicate that financial statement users perceive that a problem exists when, in fact, none does. In such a situation, the public policy choices are to either 1) educate users about the facts, or 2) develop a regulatory response that will satisfy users' perceptions. The SEC and PCAOB appear to be moving in the latter direction.

Why might lenders react differently to tax services than FISDIS? If tax services are typically more enduring in nature, perhaps lenders believe these services have a stronger impact on the economic bond between auditors and their clients. Federal and state regulators would benefit from additional information on the characteristics of FISDIS and tax services that affect perceptions of auditor independence.

This study is subject to certain limitations. First, while we took care to construct our instrument, including using industry data from Robert Morris Associates and conducting extensive pilot testing with loan officers, it is nonetheless possible that in trying to keep the case to a reasonable length, we may have omitted information relevant to the lenders' perceptions and judgments. Second, our response rate of approximately nine percent is low. While our analysis shows no significant difference between early and late responders, we cannot rule out the possibility that non-respondents may have replied differently. Third, our cell sizes are somewhat low, limiting the power of our tests. In particular, while we find a weak association between providing tax services and perceptions of auditor independence, future research is necessary to confirm this relationship.

\section{AUTHOR INFORMATION}

Gary Colbert is an Associate Professor of Accounting at the University of Colorado Denver. Professor Colbert received his Ph.D. from the University of Oregon. His research interests include audit quality, the regulation of the accounting profession and managerial accounting. Professor Colbert has published in a wide variety of academic and professional journals including Research in Accounting Regulation, Journal of Regulatory Economics, Accounting Horizons, Journal of Accounting, Auditing and Finance, Auditing: A Journal of Practice and Theory and Accounting Organizations and Society.

Dennis Murray is a Professor of Accounting at the University of Colorado Denver. Professor Murray received his $\mathrm{Ph} . \mathrm{D}$. from the University of Massachusetts. His interests include financial reporting and the regulation of the accounting profession. Professor Murray has published in a wide variety of academic and professional journals including The Accounting Review, Journal of Regulatory Economics, Accounting Horizons, Journal of Accounting, Auditing and Finance, Journal of Accounting and Economics and Journal of Accounting Research.

Robert J. Nieschwietz is an Assistant Professor of Accounting at the University of Colorado Denver. Professor Nieschwietz received his Ph.D. from Arizona State University. His research interests include auditor independence, fraud, and the impact of technology on decision making and auditing. Professor Nieschwietz has published in various journals including the Journal of Accounting Literature, the International Journal of Accounting Information Systems, the International Journal of Auditing, and the Journal of Accounting Education. 


\section{REFERENCES}

1. Ashbaugh, H., R. LaFond, and B. W. Mayhew. 2003. Do nonaudit services compromise auditor independence? Further evidence. The Accounting Review 78 (July): 611-639.

2. $\quad$ Beck, P. J., T. J. Frecka, and I. Solomon. 1988a. A model of the market for MAS and audit services: Knowledge spillovers and auditor-auditee bonding. Journal of Accounting Literature 7: 50-64.

3. , and 1988b. An empirical analysis of the relationship between MAS involvement and auditor tenure: Implications for auditor independence. Journal of Accounting Literature 7: 65-84.

4. Blackwell, D. W., T. R. Noland, and D. B. Winters. 1998. The value of auditor assurance: Evidence from loan pricing. Journal of Accounting Research 36 (Spring): 57-70.

5. Chung, H., and S. Kallapur. 2003. Client importance, nonaudit services, and abnormal accruals. The Accounting Review 78 (October): 931-955.

6. DeFond, M. L., J. R. Francis. 2005. Audit Research after Sarbanes-Oxley. Auditing: A Journal of Practice and Theory 24 (Supplement): 5-30.

7. Dopuch, N., R. R. King, and R. Schwartz. 2003. Independence in appearance and in fact: An empirical investigation. Contemporary Accounting Research 20 (Spring): 79-111).

8. Frankel, R. M., M. F. Johnson, and K. K. Nelson. 2002 The relation between auditors' fees for nonaudit services and earnings management. The Accounting Review 77 (Supplement): 71-105.

9. Jenkins, G. J. and K. Krawczyk. 2003. The Influence of nonaudit services on perceptions of auditor independence. Journal of Applied Business Research (17)3: 73-78.

10. Kinney Jr., W. R., Z. Palmrose, and S. Scholz. 2004. Auditor independence, non-audit services, and restatements: Was the U. S. government right? Journal of Accounting Research 42 (June): 561-588.

11. Krishnan, J., H. Sami, and Y. Zhang. 2005. Does the provision of nonaudit services affect investor perceptions of auditor independence? Auditing: A Journal of Practice and Theory 24 (2): 111-135.

12. Lowe, D. J., M. A. Geiger, and K. Pany. 1999. The effects of internal audit outsourcing on perceived external auditor independence. Auditing: A Journal of Practice and Theory 18 (Supplement): 7-26.

13. K. Kany. 1995. CPA performance of consulting engagements with audit clients: Effects on financial statement users' perceptions and decisions. Auditing: A Journal of Practice and Theory 14 (Fall) 35-53.

14. McKinley, S., K. Pany, and P. M. J. Reckers. 1985. An examination of the influence of CPA firm type, size, and MAS provision on loan officer decisions and perceptions. Journal of Accounting Research 23 (Autumn): 887-896.

15. Menon, K., and D. D. Williams. 2004. Former audit partners and abnormal accruals. The Accounting Review 79 (October): 1095-1118.

16. Mishra, S, K. Ragnunandan, D. V. Rama. 2005. Do investors' perceptions vary with types of nonaudit fees? Evidence from auditor ratification voting. Auditing: A Journal of Practice and Theory 24 (2): 9-25.

17. Neter, J., W. Wasserman, and M. H. Kutner. 1985. Applied Linear Statistical Models, $2^{\text {nd }}$ Edition, Homewood, IL: Irwin.

18. Pany, K. and P. M. J. Reckers. 1983. Auditor independence and nonaudit services: Director views and their policy implications. Journal of Accounting and Public Policy (Spring): 43-62.

19. Pany, K., and P. Reckers. 1987. Within vs. between-subjects experimental designs: A study of demand effects. Auditing: A Journal of Practice and Theory 6 (Fall): 39-53.

20. $\quad$ 1988. Auditor performance of MAS: A study of its effects on decisions and perceptions. Accounting Horizons (2) 2: 31-38.

21. Public Company Accounting Oversight Board (PCAOB). 2004. Auditor Independence and Tax Services Roundtable Briefing Paper. Washington. D. C.: PCAOB.

22. Reynolds, J. K., D. R. Deis, Jr., and J. R. Francis. 2004. Professional service fees and auditor objectivity. Auditing: A Journal of Practice and Theory. 23 (March): 29-52.

23. Securities and Exchange Commission (SEC). 2000. Final Rule: Revision of the Commission's Auditor Independence Requirements. Release Nos. 33-7919; 34-43602; 35-27279; IC-IA-1911, FR-56, File No. S713-00. Washington, D. C.: SEC. 
24. _ 2003. Final Rule: Strengthening the Commission's Requirements Regarding Auditor

Independence. Release Nos. 33-8183; 34-47265; 35-27642; IC-25915; IA-2103, FR-68, File No. S7-49-02. Washington, D. C.: SEC.

25. Schipper, K. 1991. Commentary: On analysts' forecasts. Accounting Horizons (December): 105-121.

26. Shockley, R. A. 1981. Perceptions of auditors' independence: An empirical analysis. The Accounting Review 56 (October): 785-800.

27. Simunic, D. 1984. Auditing, consulting, and auditor independence. Journal of Accounting Research 22(Autumn): 692-702.

\section{ENDNOTES}

\footnotetext{
${ }^{1}$ Dopuch et al. (2003) provide recent experimental markets evidence dealing with independence in appearance. However, they are concerned with the effect of inconsistencies between independence in fact and appearance, rather than with whether providing NAS affect independence in appearance.

${ }^{2}$ For example, Pany and Reckers (1983) found that the judgments and perceptions of U.S. corporate directors were more negatively impacted by system design services than tax preparation services procured from auditors. Also, Jenkins and Krawczyk (2003) found that CPA firm professionals and general public subjects did not view tax preparation services as impairing auditor independence. Neither study employs likely financial statement users as subjects.
}

${ }^{3}$ The resulting response rate is lower than that found in earlier similar studies. Schipper (1991) outlines difficulties in obtaining data from financial statement users. Perhaps these difficulties are increasing over time. Also, subjects may be increasingly resistant to participate in response to the frequent requests they receive.

${ }^{4}$ Participants were told that the applicant received an unqualified opinion for both years.

${ }^{5}$ The NAS fees actually presented to the participants were modified by $\$ 500$ from the indicated set percentage of the audit fee. Given that two years of data were presented, subjects might have been able to infer our fee setting rule without such a modification.

${ }^{6}$ Subjects were also asked to indicate the interest rate premium they would charge if they granted the loan. A number of respondents that indicated they would not give the loan did not respond to the interest rate premium question. Because of this, the variable was not included in the analysis.

${ }^{7}$ Eleven subjects failed to identify whether there were prior audit fees and seven more had no prior loan experience of this size. We repeated our analysis including all subjects. The results and conclusions are substantially unchanged as those reported in the paper.

${ }^{8}$ The possibility of demographic differences across the groups was analyzed using one-way ANOVAs. No significant differences were found.

${ }^{9} \mathrm{We}$ also performed diagnostics to investigate deviations from assumptions underlying the ANOVA models. ANOVA assumes equal variances across the groups studied and that the error terms are normally distributed. Using the Cochran and Bartlett-Box tests we find the variances are homogeneous. Tests for skewness suggest that the error terms in several of our ANOVA models are not normally distributed. This is likely due to the use of 11-point Likert scales in our dependent variables. For cases similar to ours, Neter et al. (1985) indicate that the effects of these departures from the model assumptions are slight. As an alternative we also performed Kruskal-Wallis nonparametric tests that yielded essentially the same results as those in the ANOVAs reported below.

10 The ANOVA results for tax services are based on an analysis of overall means including subjects in cells where the treatment includes FISDIS services present. A t-test of the cell means without FISDIS present (Group 1: No tax services versus Group 2: Tax services) was also conducted. Results from this test further support the effect of tax services on both perceptions of confidence in independence $(\mathrm{p}$-value $=.06)$ and financial statement reliability $(\mathrm{p}$-value $=.07)$. 